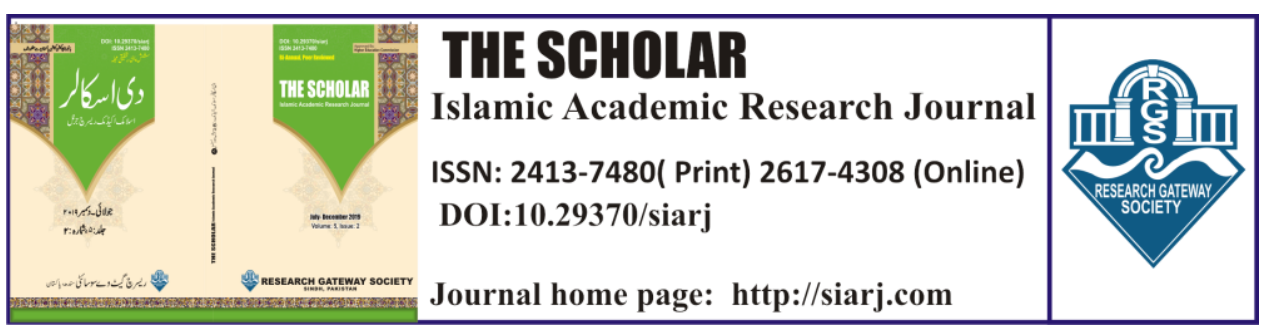

\title{
AN ANALYTICAL STUDY OF TRADITIONS OF TRIAL AND TRIBULATION IN THE LIGHT OF SIX CANONICAL BOOKS
}

\section{Peeral khan}

PhD Scholar, Department of Comparative

Religion \& Islamic Culture · University of

Sindh, Jamshoro

Email: hpeeral@gmail.com

ORCIID IID:

https://orcid.org/0000-0002-2229-7509

\section{Dr. Naheed Arain}

Associate Professor, Department of comparative Religion \& Islamic Culture, University of Sindh, Jamshoro, Pakistan Email: arainnaheed@gmail.com

ORCID ID:

https://orcid.org/0000-0002-9690-8675

\section{Dr. Jabeen Bhutto}

Assistant Professor, Department of Comparative Religion \& Islamic Culture, Sindh University, Jamshoro, Pakistan

Email: drbhuttojabeen@gmail.com

ORCIID IID:

https://orcid.org/0000-0001-9038-0171

To cite this article:

Khan, Peeral, Naheed Arain, and Jabeen Bhutto. "AN ANALYTICAL STUDY OF TRADITIONS OF TRIAL AND TRIBULATION IN THE LIGHT OF SIX

CANONICL BOOKS." The Scholar-Islamic Academic Research Journal 5, No. 2 (December 16, 2019): 100-127.

To link to this article: https://doi.org/10.29370/siarj/issue9ar12

\begin{tabular}{|c|c|}
\hline Journal & $\begin{array}{l}\text { The Scholar Islamic Academic Research Journal } \\
\text { Vol. 5, No. } 2 \text { || July -December 2019||P.100-127 } \\
\text { Research Gateway Society }\end{array}$ \\
\hline$\frac{\text { Publisher }}{\text { DOI: }}$ & $\begin{array}{l}\text { Research Gateway Society } \\
\text { 10.29370/siari/issue9ar12 }\end{array}$ \\
\hline URL: & https://doi.org/10.29370/siarj/issue9ar12 \\
\hline License: & Copyright c 2017 NC-SA 4.0 \\
\hline Journal homepage & www.siari.com \\
\hline Published online: & $2019-16-12$ \\
\hline
\end{tabular}

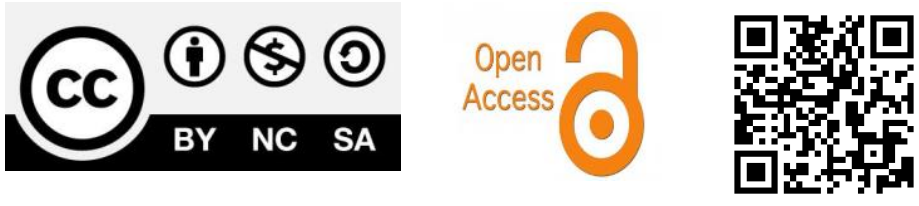


THE SCHOLAR (July - December 2019)

\title{
AN ANALYTICAL STUDY OF TRADITIONS OF TRIAL AND \\ TRIBULATION IN THE LIGHT OF SIX CANONICAL BOOKS
}

\author{
Peeral khan, Naheed Arain, Jabeen Bhutto
}

\begin{abstract}
:
The purpose of this research study is to deduce some key issues of Muslims regarding their negligence from the trial and tribulation of this world and suggests some way outs for their pleasant existence in this mundane world. Allah (S.W.T) has blessed human beings with free will in choosing good and evil, having imparted the knowledge of both spheres. It is necessary for the seeker of goodness to gain objective information about both good and evil. Some of the companions of Holy prophet collected information from him about virtue, while some about vice. They conveyed what they learned in the context of the traditions of trial and tribulation to their followers, who passed it through the stages of editing to the Muslim Community in the form of collections. This information is as important as the protection of beliefs or creeds. Since the traditions of tribulation are related to purely practical world, and have to do with human life, human dignity and human wealth. It is very important to acquire their knowledge in purview of the correct context and authentication. However, the study points out the lack of acquaintance of the authentic knowledge of the Ahādith by layman and sticking to whims has led to the chaos and confusion and has put Muslim community in the depth of degradation, study also recommends some remedies to avert from the situation and stick to path of guidance.
\end{abstract}

KEYWORDS: Antichrist, Concocted, Tribulations, Connotation, Harbinger, Covetousness, Carnage, Unsheathed, Dilemma, Manifestation, Infernal 


\section{INTRODUCTION}

Allah created the life and death of a human being to test its actions and deeds to determine who is sticks to good deeds and who performs the evil deeds ${ }^{1}$. By showing the paths of both, He has chosen to take either of them in whichever way he wishes and avoids whomever he wishes to avoid ${ }^{2}$. If a person is possessed by nature and has an inclination of goodness in his temperament, Allah has made the path of guidance and goodness easy for him. At times Allah leaves man behind the circumstances that cause him to fall into ruin and destruction because of his personal misguidance and power $^{3}$. Therefore, it is necessary for man to avoid the sins and temptations to raise the issue. In this case the divine teachings can become the tool of its guidance. ${ }^{4}$

To walk on the right path, it must be recognized that virtue and evil can be distinguished. There is the potential for distinguishing between good and evil. On the other hand, there is probability of misunderstanding the bad as good which in the system of Allah is being counted in the deeds of evil. That same point was ignored by the followers of Christianity and they turned their attention to the actions which led them to astray. Consequently they fell in the depth of dungeon and are groaning under the pangs of oppression and tyranny. This aspect has been of the utmost importance in the case of Islam. And the work of discerning, evaluating and discriminating against evil is in progress.

\footnotetext{
${ }^{1}$ Al-Qurān :(67)2.

${ }^{2}$ Al-Qurān :(76)3

3 Al-Qurān :(2)26.

4 Al-Qurān :(2)2.
} 
Following questions have been answered in this research article.

1-What is the cone and prose of those Ahāāith in which prophet (P.B.U.H) has warned the Ummah regarding such havoc and chaos.

2-Which havocs have emerged and their whereabouts and which are still awaited

3- Which methods has been indicated as precaution from such trials and temptations

\section{LITERATURE REVIEW}

Islamic scholars have pen down only on the veracity of the Prophethood. Such content is mostly found in the books written in the context of the miracle of Holy Prophet Muhammed (S.A.W). Most of the books have depicted those prophecies as emotional, stunning and concocted. Merely imaginary topics dealing with Gog Magog, Masih (savior \& deliverer) and his battles with enemies have been depicted in order to attract and draw the attention of laymen. Following are the books which have attained great acclaim among common and sundry peoples:

1- Abu UmerAasim, Dajjal ka lashker black water. (karachi :Al hijra publications)

2- Abul fida Imaduddin Ibn e Kasir ,Alnihay fil fitn wal malahim

3- Ahmed Thomson, Dajjal ek fitna, translator Anjum sultan, (lahore: Haq publication 2005)

4- Israe Aalm Dehlvi,YasrruljabalkiaDajjalkeaamadaamad hay,(New Dehli. India: Darululoom 2002)

5- Muhammed Jamal Uddin Ameen,Ummat e Muslima ke Umar,Tranlator ( Lahore Khursheed Aalam , Maktabe markaze Anjuman, 2003)

6- Mufti Nizamuddin shamzai, Aqeeda e Zahoor e Mehdi Ahāāithki Roshni me. (Lahore:Al faisal printer, Muhammed Abdul Majeed Siddique, DunyaJangoonkedehaney per, feroz sons pvt limited 1999) 
7- Sahbbir Ahmed Azher Merithey,Ahạāith e Dajjal ka tahqiq iMutaliya,( Lahor: daruttazkir urdu bazar, 2005)

8- Abu Umer Aasim Bermodatakoon our Dajjal, (karachi: Al hijra publications)

9- Abu Umer Aasim, Teesreejange Azeem or Dajjal, (karachi :Al hijra publications)

\section{OBJECTIVES OF RESEARCH :}

These are the few examples of such books. Either partial or total denial has been demonstrated about future tells and the basic fact behind such misconception is due to the deduction of results from such Ahādīth without verification. It is, therefore, most demanding aspect to be analyzed and researched. Such all Ahāaīth be gathered together and their analytical and critical study should be shouldered to tackle such issues and save the Muslim Community from this trial and temptation.

\section{THE PROPHETIC PROCEDURE OF AWARENESS ABOUT TRIBULATIONS:}

Prophet (peace be upon him) warned his nation of every mischief that could cause them to suffer. This's why he made a special point to one of the great temptations is that about of the Antichrist (Christ-al-Dajjal). Holy Prophet said not only I am warning you but all the prophets who came before me to the world have informed and warned their nations as well. ${ }^{5}$

In some places, in the context of the fear that someone might not be able to understand a point about the Antichrist, he had explained it in a very clear way so that everyone can understand. ${ }^{6}$ The following words "I make you

\footnotetext{
${ }^{5}$ Abu Abdullah Muhammed Bin Yazid Al Kazveni, Ibn-e-Maja (Cairo, Sunan Ibn-eMaja, Ahyaul Kutub al Arbia,

, Cairo,vol 1.p-116)

${ }^{6}$ Abu Daud Sulaiman Bin Ashat Assajastani, Sunan-e-abu daud (Daru Hadith letaba wannaser, Beirut, Hadith-4320)
} 


\section{An Analytical Study of Traditions of Trial and Tribulation in The Light of Six Canonical Books}

afraid of the crucifixion of Christ al-Dajjal ${ }^{7 "}$ it shows that awareness of tribulations is one of the most scholarly and important topics for the believers.

\section{COMPANIONS METHOD OF WARNING ABOUT TRIBULATION:}

Hazrat Huzefa bin Yaman (RA) is one of those companions who has spent a long time in the companionship of the Prophet (P.B.U.H) and has narrated a large number of traditions from him. Once he said mostly peoples used to come to Holy Prophet (peace be upon him) to get education about virtues while I used to inquire about how to get rid from vices and evil ${ }^{8}$. That's why when he visited other areas, people's gathered around him and talk to him about those things i-e Acquiring knowledge related to evil so that it could be avoided to get rid of these conditions by following the straight path. According to the tradition of Abu Tufail and Umar bin Saliyah in the, a large number of people used to sit around Hazrat Huzefa Bin Yaman and ask him questions about the tribulations ${ }^{9}$. After gaining awareness about this, the task of spreading it to the public was done by the great enthusiasm.

\section{THE CURE OF IGNORANCE IN THE TRADITIONS OF TRIBULATION:}

The attraction of the good and the promotion of the virtues in the pious companions were immense, because the world would suffer great temptations because of the decline of the virtues of righteousness. So a person announced that the Antichrist has appeared. He met Hazrat Saab

\footnotetext{
${ }^{7}$ Ahmed bin Hambal Asshebani, Al Masnad, (Al Maktabtul Islami Beirut, vol-5, page364)

${ }^{8}$ Muahmmad bin Ismaeel Bukhari, Al Jameussahih, (Beriut,lebnon: Dare Ahyautturas Al arbi, 3607)

${ }^{9}$ Abu Abdullah Muhammed Bin Abdullah Al Hakim Nishpoori, Mustadrik Alssahihain (Beirut:Darul kutub Aleemiya, vol 4, P,516)
} 


\section{An Analytical Study of Traditions of Trial and Tribulation in The Light of Six Canonical Books}

Bin Jisamah, and then a companion rejected the announcer's announcement and replied, "I have heard the Prophet (P.B.U.H) saying that the Antichrist will come into the world when the people will shun remembrance of Allah, even the religious scholars will abandon it too while delivering their speeches to peoples ${ }^{10}$. The Companions used to distinguish them on the basis of the knowledge of the Ahādīth related to temptations. In the latter tradition, the Prophet's companion denial regarding the appearance of the Dajjal shows their knowledge with sagacity and confirmation.

\section{NEED TO BE ALERT AND ALARM OTHERS FROM TRIBULATION:}

Since the traditions of faith are related to purely scientific and practical world, it is very important to acquire their knowledge and to preach it to others. Otherwise, all the people of the Ummah will gradually suffer from temptations and suffer from such a loss, which will have to bear for generations. The companions had in insight of this idea. Therefore, any event that came to their knowledge that could have been the basis of the chaos and confusion in the Ummah was condemned. Some of the companions also did a special job of inviting their companions to keep away from temptations. Ahnaf Bin Qais narrates, "I went to help one of the two persons in a state of war. On the way I met Hazrat Abu Bakr. He asked me where I was going; I told him that I was going to help one person in a fight. He advised me to go back because I heard the Prophet (P.B.U.H) telling me that when two Muslims pull out swords, they fight. Both the murderer and the murdered will go to the infernal. The murdered will go to hell because he too was planning to kill his partner.

\footnotetext{
10 Ahmed bin Hambal Asshebani, Al Masnad, (Beirut: Al Maktabtul Islami vol-4, p-71)
} 


\section{An Analytical Study of Traditions of Trial and Tribulation in The Light of Six Canonical Books}

\section{AVERSION FROM TRIBULATION:}

The Prophet (peace and blessings of Allah be upon him) had infused the sense of aversion in minds and hearts of his companion. During his sermons, he used to tell the future news in a very delicate way that any intelligent human being listened to them could he easily averted himself from such tribulations, Prophet (P.B.U.H) had warned about the severity of the temptations in such a way that he was seeing them himself. In this regard, he warned the Companions to avoid these temptations to safeguard their faith. Hazrat Abu Bakr, mentioned in the previous Hadīth, had a son Muslim bin Abu Bakar.

$$
\begin{aligned}
& \text { "سمعت أبا بكرة يحلِّث، قال: قال رسول الله - - } \\
& \text { القاعلُ فيها خيرٌ من الماشي فيها، والماشي فيها خير من الساعي إليها--الخ-- }
\end{aligned}
$$

"There would soon be turmoil. Behold! There would be turmoil in which the one who would be seated would be better than one who would stand and the one who would stand would be better than one who would run. Behold! when the turmoil comes or it appears, the one who has camel should stick to his camel and he who has sheep or goat should stick to his sheep and goat and he who has land should stick to the land. A person said: 'Allah's Messenger, what is your opinion about one who has neither camel nor sheep nor land? Thereupon, he said: He should take hold of his sword and beat its edge with the help of stone and then try to find a way of escape. O Allah, I have conveyed (Thy Message); O Allah, I have conveyed (Thy Message) ; O Allah, I have conveyed (Thy Message).A person said: Allah's Messenger, what is your opinion if I am drawn to a rank in spite of myself, or in one of the groups and made to march and a man strikes with 


\section{An Analytical Study of Traditions of Trial and Tribulation in The Light of Six Canonical Books}

his sword or there comes an arrow and kills me? Thereupon he said: He will bear the punishment of his sin and that of yours and he would be one amongst the denizens of Hell. ${ }^{11}$

So the books of the Ahāaīth point to all the issues that have to do with trial and tribulation. Prophet (P.B.U.H) has gone to such an extent that he depicted the world as house of tribulation. He said it in following words "Nothing would be left in the world except temptation" ${ }^{12 "}$.

\section{THE SANCTITY OF HUMAN LIFE, WEALTH AND HONOR:}

These tribulations have to do with human life, human dignity and human wealth. Therefore, in some places, the Prophet (peace be upon him) had specifically warned his companions about all these things. Imam Bukhari has narrated a Hadith in this regard, According to him; Prophet (P.B.U.H) warned the Companions that the blood of Muslims, the wealth of the Muslims and their dignity is the same as the sanctity of the month of Zil-Hajj, the day of sacrifice and the city of Makkah. Prophet (P.B.U.H) not only signify the sanctity of these this but clearly ordered that anyone who listens to these teachings should carry out their preaching to others as well ${ }^{13}$.

In the books of Ahādīth, the use of human wealth in illicit means of obtaining and using illicit methods is prescribed as a precursor to the appearance of dooms day and the humiliation. Abu Hurairah has narrated

\footnotetext{
${ }^{11}$ Abul Hassan Muslim Bin Hajjaj Al Qasheri, Sahih Muslim (Istanbul: Al Maktabtul Islamiya, 2887)

${ }^{12}$ Abu Abdullah Muhammed Bin Yazid Alqazveni, Ibn-e-Maja Sunan Ibn-e-Maja (Cairo,Ahyaul Kutub al Arbia H-4035)

${ }^{13}$ Muahmmad bin Ismaeel Bukhari, Al Jameussahih, (Beriut,lebnon: Dare Ahyautturas Al arbi, 67)
} 


\section{An Analytical Study of Traditions of Trial and Tribulation in The Light of Six Canonical Books}

that people will start gaining the worldly profits from the religious preaching $^{14}$.

\section{CONSEQUENCE OF IGNORING THE TRADITIONS OF TRIBULATIONS:}

There are several Ahādīth related to the nature of these temptations, in the light of which we know that Holy prophet has not missed any precise attempt to clarify this topic. Every person is warned to not let him be tainted, but stay away from it Holy prophet has even made known the names of the trials, without any tinge of doubt. Hazrat Abu Hurairah (RA) says that the Holy prophet said:

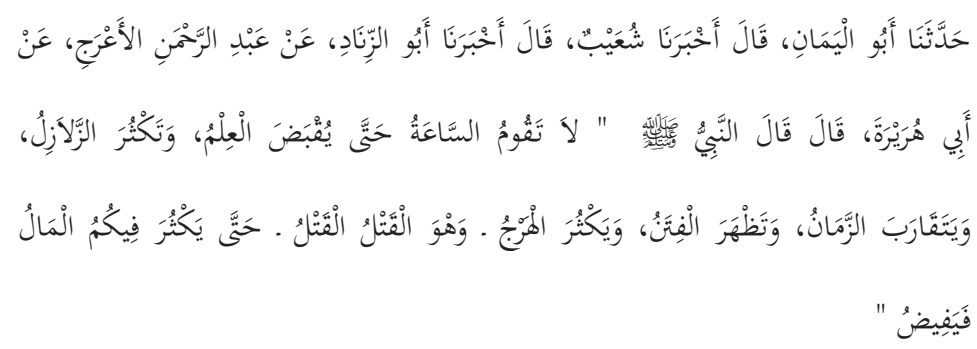

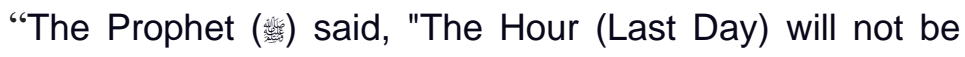
established until (religious) knowledge will be taken away (by the death of religious learned men), earthquakes will be very frequent, time will pass quickly, afflictions will appear, murders will increase and money will overflow amongst you." 15

\footnotetext{
${ }^{14}$ Muhammad ibn 'Īsá ibn Sawrah Jami' at-Tirmidhii (Hamas: Maktabh Daruddawah, ,2211)

${ }^{15}$ Muahmmad bin Ismaeel Bukhari, Al Jameussahih, (Beriut,lebnon :Dare Ahyautturas Al arbi,7121)
} 
The Scholar Islamic Academic Research Journal

Vol. 5, No. 2 || July -December 2019 || P. 100-127

https://doi.org/10.29370/siarj/issue8ar12

In the above Hadith, a map of worldly conditions has been presented after the rise of knowledge, which shows that Holy prophet had informed the companions about the importance of acquiring knowledge about this aspect. He said,

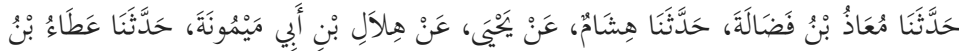

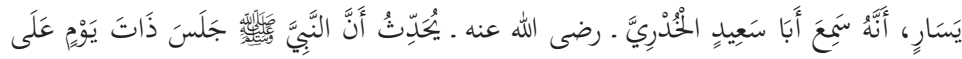

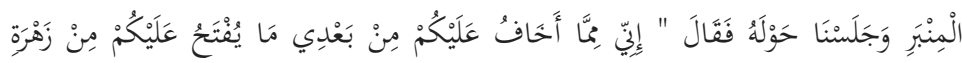

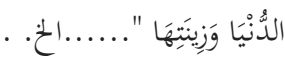

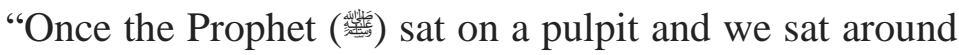
him. Then he said, "The things I am afraid of most for your sake (concerning what will befall you after me) is the pleasures and splendors of the world and its beauties which will be disclosed to you." Somebody said, "O Allah's Messenger (鄢)! Can the good bring forth evil?" The Prophet (繼) remained silent for a while. It was said to that person, "What is wrong with you? You are talking to the Prophet (p.b.u.h) while he is not talking to you." Then we noticed that he was being inspired divinely. Then the Prophet (酸) wiped off his sweat and said, "Where is the questioner?" It seemed as if the Prophet liked his question. Then he said, "Good never brings forth evil. Indeed it is like what grows on the banks of a water-stream which either kill or make the animals sick, except if an animal eats its fill the Khadra (a kind of vegetable) and then faces the sun, and then defecates and urinates and grazes again. No doubt this 
The Scholar Islamic Academic Research Journal

Vol. 5, No. 2 || July -December 2019 || P. 100-127

https://doi.org/10.29370/siarj/issue8ar12

wealth is sweet and green. Blessed is the wealth of a Muslim from which he gives to the poor, the orphans and to needy travelers. (Or the Prophet said something similar to it) No doubt, whoever takes it illegally will be like the one who eats but is never satisfied, and his wealth will be a witness against him on the Day of Resurrection." 16

Prophet also said: "I have left no such big tribulation for my Ummahs' men than the women ${ }^{17,}$

Prophet has left the teachings for future human beings, in the light of which everyone can save their time by recognizing the evil and mischief of their own time but the listener and gainer should have sound mind. The person who already has the inclination towards evil will fall prey to these temptations.

The hearts will be divided into two types. The first kind will have hearts like lubricating stones, which will have no temptation and the survival of the world will be possible by such people while the hearts of the other types would be whitish black. They will not consider the importance of any good or avoid any evil ${ }^{18}$.

It is understood that acquiring knowledge about temptations, preaching and disseminating this knowledge to others is an obligation that could endanger human survival in the world itself. That is why Prophet

\footnotetext{
${ }^{16}$ Muahmmad bin Ismaeel Bukhari, Al Jameussahih, (Beriut,lebnon: Dare Ahyautturas Al arbi, 115)

${ }^{17}$ Muahmmad bin Ismaeel Bukhari, Al Jameussahih, (Beriut,lebnon :Dare Ahyautturas Al arbi, 5096)

${ }^{18}$ Muahmmad bin Ismaeel Bukhari, Al Jameussahih, (Beriut,lebnon :Dare Ahyautturas Al arbi, 144)
} 
The Scholar Islamic Academic Research Journal

Vol. 5, No. 2 || July -December 2019 || P. 100-127

https://doi.org/10.29370/siarj/issue8ar12

(P.B.U.H) himself, in view of the magnitude of the temptations prayed to seek Allah's protection in such an obligation.

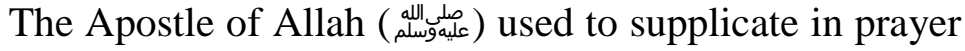
thus:" O Allah! I seek refuge with Thee from the torment of the grave, and I seek refuge with Thee from the trial of the Masih al-Dajjal (Antichrist) and I seek refuge with Thee from the trial of life and death. O Allah! I seek refuge with Thee from sin and debt." She ('A'isha) reported: Someone said to him - (the Holy Prophet): Messenger of Allah! Why is it that you so often seek refuge from debt? He said: When a (person) incurs debt, (he is obliged) to tell lies and break promise. ${ }^{19}$.

\section{PROPHETIC TRADITIONS OF WARNING OF IMPORTANT TRIBULATIONS:}

For the seeker of the world, the world is not a trial, but a life of purpose, while for the seeker of the religion, the world is no less than a prison. Some timed the religious people also fell prey to the worldly charm and thereby jeopardizes his Faith. Holy Prophet (P.B.U.H) fully realized this concern and informed the companions of it. Abu Saeed Khadri narrates that prophet said:

"I am afraid that after me the adornment of the world will be opened for you people". He also added: "This wealth is also a pleasant meadow. How good is the wealth of a Muslim which is given to the poor, orphan and travelers? If any person takes Zakat without being entitled, then his example is like that of a person who eats but does not satisfy his

\footnotetext{
${ }^{19}$ Muahmmad bin Ismaeel Bukhari, Al Jameussahih, (Beriut,lebnon: Dare Ahyautturas Al arbi, 832)
} 
The Scholar Islamic Academic Research Journal

Vol. 5, No. 2 || July -December 2019 || P. 100-127

https://doi.org/10.29370/siarj/issue8ar12

appetite. On the Day of Judgment, this wealth will be a witness against him"20.

In the light of the traditions, it is known that whenever a Prophet (P.B.U.H) was aware of a temptation, he himself would witness it and warn others. Purification of hearts, code of Sharia, and warning against trial and tribulation was also included in the prophetic task of the last prophet. This is why when prophet (P.B.U.H) was informed about Ibn Sayyad, he took Hazrat Umar (RA) with him and went to meet him ${ }^{21}$. It was possible that a listener might have overlooked this verdict by giving an exception to this verdict. But he repeatedly made clear this aspect of education and preaching so that every preacher, teacher, propagator and missionary could do his best. Along with the propagation of evil, he also signified evil. Usama bin Zaid said that the Prophet (peace and blessings of Allah be upon him) said: "I see the demons descending into your homes as the droplets of rain fall from the sky to the ground. ${ }^{22,}$

Similarly, explaining the signs of the Antichrist in the Ahādīth related to the Dajjal (a detailed account of which will be forthcoming) is a manifestation of this concern.

When will the temptations take place and which one follow the other, has caused a great havoc. Some of the weak and concocted traditions are well known in this regard, due to which ignorance has emerged in the form of a new deception. Determining the time of the Prophet (SAW), he said that

\footnotetext{
${ }^{20}$ Muahmmad bin Ismaeel Bukhari, Al Jameussahih, (Beriut,lebnon: Dare Ahyautturas Al arbi, 1465)

${ }^{21}$ Muahmmad bin Ismaeel Bukhari, Al Jameussahih, (Beriut,lebnon: Dare Ahyautturas Al arbi, 1354)

22 Muahmmad bin Ismaeel Bukhari, Al Jameussahih, (Beriut,lebnon :Dare Ahyautturas Al arbi, 1878)
} 
The Scholar Islamic Academic Research Journal

Vol. 5, No. 2 || July -December 2019 || P. 100-127

https://doi.org/10.29370/siarj/issue8ar12

tribulation will start rising after 200 years of his demise.

The fact is that this tradition has been termed as concocted by the Muhaddithin $^{23}$. Therefore, it is necessary that such traditions authentication should be thoroughly assayed and investigated and the reality be brought out before the people about such famous weak or concocted traditions. So that, no Muslim would be involved in any of the major trials.

Another tradition Hazrat Anas (RA) said that after the Prophet (peace be upon him) for forty years people remain pious, for next century the people remain merciful and for the next hundred years people who broke the relationship, later people start killing each other. For, every Muslim should seek refuge of Allah ${ }^{24}$. Imam Ahmad Ibn Hambal has also quoted another tradition of same concept which commented that "one should not hit each other's necks in disbelief and misguidance after me" 25 .

\section{ADMONITION TO THE PEOPLE OF THE EAST:}

The Prophet has also suggested the Ummah to stay away from the temptations in various forms. And it is possible to avoid countries where his faith is at stake. In this regard, he pointed to the eastern regions and said that from these areas the horn of demons would rise ${ }^{26}$. Concerning the fatal blow, he also said that in the future, other people would be given priority over Muhajreen and Ansar (the immigrant and the helper)

\footnotetext{
${ }^{23}$ Abu Abdullah Muhammed Bin Yazid Al Kazveni, Ibn-e-Maja Sunan Ibn-e-Maja, (Cairo Ahyaul Kutub al Arbia, ,4057)

${ }^{24}$ Abu Abdullah Muhammed Bin Yazid Al Kazveni, Ibn-e-Maja Sunan Ibn-e-Maja, (Cairo: Ahyaul Kutub al Arbia, ,4059

${ }^{25}$ Ahmed bin Hambal Asshebani, Al Masnad,( Beirut: Al Maktabtul Islami vol-4Pg:76)

${ }^{26}$ Muahmmad bin Ismaeel Bukhari, Al Jameussahih, (Beriut: lebnon :Dare Ahyautturas Al arbi, 3279)
} 
The Scholar Islamic Academic Research Journal

Vol. 5, No. 2 || July -December 2019 || P. 100-127

https://doi.org/10.29370/siarj/issue8ar12

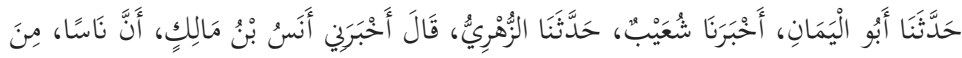

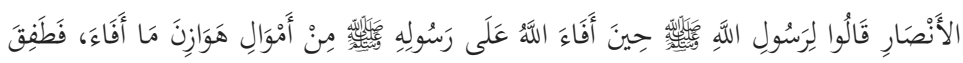

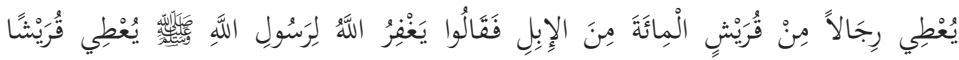

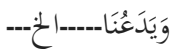

"When Allah favored His Apostle with the properties of Hawazin tribe as Fai (booty), he started giving to some Quarries men even up to one-hundred camels each, whereupon some Ansari men said about Allah's Messenger (way Allah forgive His Apostle! He is giving to (men of) Quraish and leaves us, in spite of the fact that our swords are still dropping blood (of the infidels)" When Allah's Messenger (亲) was informed of what they had said, he called the Ansar and gathered them in a leather tent and did not call anybody else along, with them. When they gathered, Allah's Messenger (镂) came to them and said, "What is the statement which, I have been informed, and that which you have said?" The learned ones among them replied," O Allah's Messenger (酻)! The wise ones amongst us did not say anything, but the youngsters amongst us said, 'May Allah forgive His Apostle; he gives the Quarish and leaves the Ansar, in spite of the fact that our swords are still dribbling (wet) with the blood of the infidels.' " Allah's Messenger (踣) replied, I give to such people as are still close to the period of Infidelity (i.e. they have recently embraced Islam and Faith is still weak in their 
The Scholar Islamic Academic Research Journal

Vol. 5, No. 2 || July -December 2019 || P. 100-127

https://doi.org/10.29370/siarj/issue8ar12

hearts). Won't you be pleased to see people go with

fortune, while you return with Allah's Messenger (㱍) to

your houses? By Allah, what you will return with, is

better than what they are returning with." The Ansar

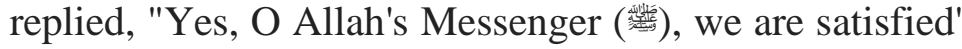

Then the Prophet (yill find after

me, others being preferred to you. Then be patient till

you meet Allah and meet His Apostle at Al-Kauthar (i.e.

a fount in Paradise)." (Anas added:) But we did not

remain patient. ${ }^{27}$.

\section{COMPULSION OF LEARNING OF TRADITIONS OF TRIBULATION:}

The purpose of this Hadith was to warn the Companions of future mischief so that they could protect their society and their state as well. These traditions importance become very clear to get the first-hand knowledge about them. Because everyone can suffer from problems that are known from the relevant traditions. So prophet (P.B.U.H) has warned every one alike in the following words:

"Then temptation would become so devastating that no Arab house would be left untouched",28.

With the knowledge of such traditions, man is capable of forming a structure that protects his feet from the filth of sins and sins. For the reason, prophet (P.B.U.H) did not conceal such knowledge but openly indicated to his follower to save their selves from the disastrous

\footnotetext{
${ }^{27}$ Muahmmad bin Ismaeel Bukhari, Al Jameussahih, (Beriut, lebnon, Dare Ahyautturas Al arbi, 3147)

${ }^{28}$.Muahmmad bin Ismaeel Bukhari, Al Jameussahih, (Beriut, lebnon :Dare Ahyautturas Al arbi, ,3176)
} 
The Scholar Islamic Academic Research Journal

Vol. 5, No. 2 || July -December 2019 || P. 100-127

https://doi.org/10.29370/siarj/issue8ar12

consequences of such tribulations.

Prophet (P.B.U.H) also said: "When the temptations come, be sitting person would be better than the one who is standing and standing person will be better than the one who walks, and the one who walks will be better than the one who runs. The peeper into these would be caught by it. During such situation wherever find refuge, just take refuge so that you can protect your religion from temptations" 29 .

The Prophet (peace and blessings of Allah be upon him) said that the knowledge of temptations was the key to success in this time of such tribulations. According to the tradition of Hazrat Abu Imama (RA), prophet said that in the confrontation of faith and unbelief, only the one who has knowledge will be safe $\mathrm{e}^{30}$.

\section{THE SCHOLARS WHO IMPLY CORRECT CONNOTATION:}

In the case of any dilemma, the believer takes the precaution for himself by turning to the Ulema and their sermons. In this case, there is a danger for the person to whom he is turning for the fatwa. Weather he writes this fatwa on the basis of the Qur'an and Sunnah or presents it only on the basis of his personal opinion. The fatwas presented on the basis of personal interpretation would contain the possibility of error

In this case, it is necessary for the scholars to consult their thought after having found an argument in the Book of Allah and the Sunnah of the Prophet (peace be upon him).

Prophet has advised to beware of any knowledgeable person who has no

\footnotetext{
${ }^{29}$ Muahmmad bin Ismaeel Bukhari, Al Jameussahih, (Beriut,lebnon Dare Ahyautturas Al arbi, ,3601)

${ }^{30}$ Abu Abdullah Muhammed Bin Yazid Al Kazveni, Ibn-e-Maja Sunan Ibn-e-Maja (Cairo: Ahyaul Kutub al Arbia 3954)
} 
The Scholar Islamic Academic Research Journal

Vol. 5, No. 2 || July -December 2019 || P. 100-127

https://doi.org/10.29370/siarj/issue8ar12

importance for Sharia texts and for that matter only the important thing which is his own mental output. Prophet has given clear teachings about in the following Hadìth:

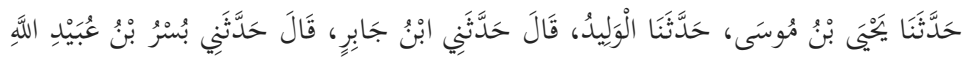

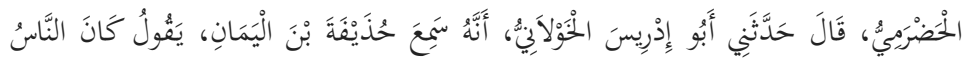

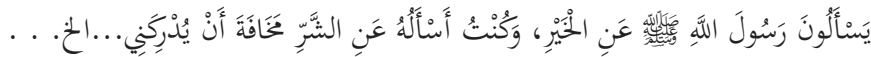

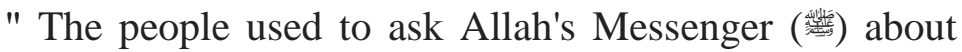
good, but I used to ask him about evil for fear that it might overtake me. Once I said, "O Allah's Messenger

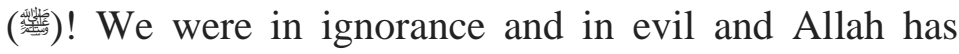
bestowed upon us the present good; will there be any evil after this good?" He said, "Yes." I asked, "Will there be good after that evil?" He said, "Yes, but it would be tained with Dakhan (i.e. little evil)." I asked, "What will it's Dakhan be?" He said, "There will be some people who will lead (people) according to principles other than my tradition. You will see their actions and disapprove of them." I said, "Will there by any evil after that good?" He said, "Yes, there will be some people who will invite others to the doors of Hell, and whoever accepts their invitation to it will be thrown in it (by them)." I said, "O Allah's Messenger ( said, "They will belong to us and speak our language" I asked, "What do you order me to do if such a thing should take place in my life?" He said, "Adhere to the group of Muslims and their Chief." I asked, "If there is neither a group (of Muslims) nor a chief (what shall I 
The Scholar Islamic Academic Research Journal

Vol. 5, No. 2 || July -December 2019 || P. 100-127

https://doi.org/10.29370/siarj/issue8ar12

do)?" He said, "Keep away from all those different sects, even if you had to bite (i.e. eat) the root of a tree, till you meet Allah while you are still in that state." ${ }^{31}$

It seems that the Prophet had a specific part in his preaching regarding the anticipated future conditions. There is a great concern for them who prefer to live in the present life and their life is merely an improvement over this situation. The element of adherence to western norms is increasing, which is why their love for Islam is eroding in their hearts. For such people prophet harbingered them that on the Day of Resurrection they will not have access to water from the reservoir Lake Fount (Aab-e-Kousar) as per the Hadith:

"The Prophet (aلd (c) said, some of my companions will come to me at my Lake Fount, and after I recognize them, they will then be taken away from me, whereupon I will say, 'My companions!' Then it will be said, 'You do not know what they innovated (new things) in the religion after you." ${ }^{32}$

The importance of acquiring and spreading this knowledge on the basis of temptations from is evident from the fact that Hazrat Hazaifa bin Yaman used this knowledge as the basis of his understanding over other companions. Because most of the traditions and Ahādīth related to temptations were memorized by him.

\footnotetext{
31 Muahmmad bin Ismaeel Bukhari, Al Jameussahih, (Beirut, lebnon: Dare Ahyautturas Al arbi, 3606)

${ }^{32}$ Muahmmad bin Ismaeel Bukhari, Al Jameussahih, (Beirut, lebnon: Dare Ahyautturas Al arbi,6593)
} 
The Scholar Islamic Academic Research Journal

Vol. 5, No. 2 || July -December 2019 || P. 100-127

https://doi.org/10.29370/siarj/issue8ar12

15. LESSON FOR THE UMMAH IN TEMPTATIONS:

The Prophet (P.B.U.H) himself urged everyone to be vigilant in regard to temptations, because at the time of the appearance of the temptations, the fear of the ignorant man still exists that he will suffer from them. The killing of human beings is considered the greatest crime on earth. Therefore, Prophet (P.B.U.H) has mentioned the killing as a special out of the appearance of temptations and also informed that the killing will be due to the absence of knowledge ${ }^{33}$. It will be a matter of the severity of the fears that a person will become a Muslim in the morning, but he will do such acts that he will be an infidel at night. The reason behind this belief is that people will give priority to world over the religion. ${ }^{34}$

The main cause of the massacre will be the covetousness. Therefore, he predicted the exit of a mountain of gold from the Euphrates River and said that the world would be united to achieve it $^{35}$. This will lead to widespread massacre and carnage. One of the reasons for the killings is mutual antagonism between nations and tribes. That is why he said that the devil hopes that the people of Arabia will worship him now, but that he will

\footnotetext{
${ }^{33}$ Muahmmad bin Ismaeel Bukhari, Al Jameussahih, (Dare Ahyautturas Al arbi, Beriut,lebnon, 7062)

34 Muhammad ibn 'Īsá ibn Sawrah Jami' at-Tirmidhii (Hamas: Maktabh Daruddawah, 2196)

${ }^{35}$ Abul Hassan Muslim Bin Hajjaj Al Qasheri, Sahih Muslim (Istanbul,:Al Maktabtul Islamiya, -2894)
} 
The Scholar Islamic Academic Research Journal

Vol. 5, No. 2 || July -December 2019 || P. 100-127

https://doi.org/10.29370/siarj/issue8ar12

provoke them to fight among themselves. ${ }^{36}$ Then once the sword unsheathed in my Ummah, It will not go back to Scabbard until the Day of Resurrection. $^{37}$

16. CONCERN ABOUT TEMPTATIONS IN THE HEART OF A TRUE BELIEVER:

For those who have the knowledge of religion and the capability and resources to broadcast it, it is necessary for them to stand with goodness in the confrontation of evil, in order to counter contemporary temptations. Such people are always concerned about the faith of themselves and their families. The Prophet's view of their concern is as follows:

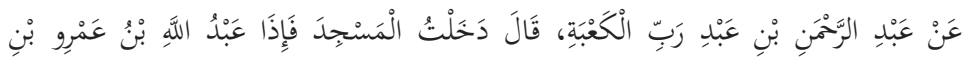

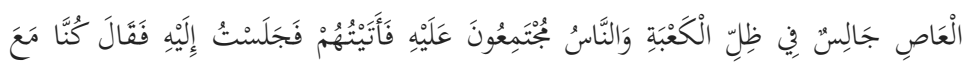

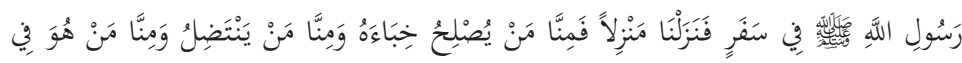

$$
\begin{aligned}
& \text { جَشَرِْ إِذْ نَاَدى -الحِ--- }
\end{aligned}
$$

"It has been narrated on the authority of 'Abd al-Rahman

b. Abd Rabb al-Ka'ba who said:

I entered the mosque when 'Abdullah b. 'Amr b. al-'As was sitting in the shade of the Ka'ba and the people had gathered around him. I betook myself to them and sat near him. (Now) Abdullah said: I accompanied the Messenger of Allah (- We halted at a place. Some of us began to set right their tents, others

\footnotetext{
${ }^{36}$ Abul Hassan Muslim Bin Hajjaj Al Qasheri, Sahih Muslim (Istanbul, AL Maktabtul Islamiya, -2812)

${ }^{37}$ Muḥammad ibn 'Îsá ibn Sawrah Jami' at-Tirmidhii (Hamas: Maktabh Daruddawah, ,2203)
} 
The Scholar Islamic Academic Research Journal

Vol. 5, No. 2 || July -December 2019 || P. 100-127

https://doi.org/10.29370/siarj/issue8ar12

began to compete with one another in shooting, and others began to graze their beasts, when an announcer of the Messenger of Allah (wanced the people should gather together for prayer, so we gathered around the Messenger of Allah (He said: It was the duty of every Prophet that has gone before me to guide his followers to what he knew was good for them and warn them against what he knew was bad for them; but this Umma of yours has its days of peace and (security) in the beginning of its career, and in the last phase of its existence it will be afflicted with trials and with things disagreeable to you. (In this phase of the Umma), there will be tremendous trials one after the other, each making the previous one dwindle into insignificance. When they would be afflicted with a trial, the believer would say: This is going to bring about my destruction. When at (the trial) is over, they would be afflicted with another trial, and the believer would say: This surely is going to be my end. Whoever wishes to be delivered from the fire and enter the garden should die with faith in Allah and the Last Day and should treat the people as he wishes to be treated by them. He who swears allegiance to a Caliph should give him the pledge of his hand and the sincerity of his heart (i. e. submit to him both outwardly as well as inwardly). He should obey him to the best of his capacity. It another man comes forward (as a claimant to Caliphate), disputing his authority, they (the Muslims) should behead the latter. 
The Scholar Islamic Academic Research Journal

Vol. 5, No. 2 || July -December 2019 || P. 100-127

https://doi.org/10.29370/siarj/issue8ar12

The narrator says: I came close to him ('Abdullah b.

'Amr b. al-'As) and said to him: Can you say on oath that you heard it from the Messenger of Allah (鵤)? $\mathrm{He}$ pointed with his hands to his ears and his heart and said: My ears heard it and my mind retained it. I said to him: This cousin of yours, Muawiya, orders us to unjustly consume our wealth among ourselves and to kill one another, while Allah says:" O ye who believe, do not consume your wealth among yourselves unjustly, unless it be trade based on mutual agreement, and do not kill yourselves. Verily, God is Merciful to you" The narrator says that (hearing this) Abdullah b. 'Amr b. al-As kept quiet for a while and then said: Obey him in so far as he is obedient to God; and disobey him in matters involving disobedience to God."

\section{NEED FOR PROPER IDENTIFICATION OF TRIBULATION:}

The Prophet (peace and blessings of Allah be upon him) has given special advice in this regard that temptations can be fought only through the teachings of the Qur'an and Sunnah. But for the immoral and the Gentiles, those who follow the tide of current wave of western modernized cultural norms have been condemned by Prophet. He declared it a sign of the Day of Judgment, ${ }^{38}$ and those who consider enemies to be immoral in their imitation and adherence to Islam.

Huzrat Huzaifa Bin Yamane advised scholars of the time in the following

\footnotetext{
${ }^{38}$ Muahmmad bin Ismaeel Bukhari, Al Jameussahih, (lebnon Beriut:Dare Ahyautturas Al arbi, 7319)
} 
The Scholar Islamic Academic Research Journal

Vol. 5, No. 2 || July -December 2019 || P. 100-127

https://doi.org/10.29370/siarj/issue8ar12

words: O reader of the Quran and Hadīth! Be steadfast because you have taken too much lead. If you do not adhere to the Qur'an and Hadīth, if you take the left or right, you will still be very astray. ${ }^{39}$

It is not surprising that the religion of the Shariah is also distorted by those who suggest partial or total adoption of temptations in the name of mediation. In cases where there is no other option but to seek guidance from the texts of the sharia, there have been many people who have interfered with the Sharia teachings or presented their contradictory traditions.

In this case, a person with knowledge of temptations can easily distinguish who is standing on the right and who is drawn to misguidance. They have nothing to do with chain or context of the authentication of Ahāaīth. Whatever they narrate neither you nor your forefathers would have heard about such traditions. ${ }^{40}$

Here the question may arise as to why the rule of distortion can be adopted in order to participate in the spread of evil and corruption on the earth? Hazrat Maaz Bin Jabal said: "The man will say: What has happened to the people? Do not follow me, even though I have read the Qur'an, they will not follow me unless I bring out something new for them. Beware to avoid such new emerging things in the religion. ${ }^{41}$

Holy prophet came into the world to unite people in unity and cohesion. Therefore, the concept of monotheism where it teaches people to worship

\footnotetext{
${ }^{39}$ Muahmmad bin Ismaeel Bukhari, Al Jameussahih, (lebnon Beriut:Dare Ahyautturas Al arbi, 7282)

${ }^{40}$ Abul Hassan Muslim Bin Hajjaj Al Qasheri, Sahih Muslim (Istanbul: Al Maktabtul Islamiya, 06)

41. Abu Daud Sulaiman Bin Ashat Assajastani, Sunan-e-abu daud (Beirut: Daru Hadith letaba wannaser, 4611)
} 
The Scholar Islamic Academic Research Journal

Vol. 5, No. 2 || July -December 2019 || P. 100-127

https://doi.org/10.29370/siarj/issue8ar12

and obey only one Lord, also teaches all human beings to come together in unity. Wherever other areas of life are affected by the multiplicity of events, the chasm of human unity is scattered. According to the tradition of Ibn 'Umar, the Prophet had predicted that this Ummah would be divided into seventy three communities and the followers of the remaining sects will become the fuel of hell fire. ${ }^{42}$

\section{KNOWLEDGE OF TEMPTATIONS IS RELATED TO PRACTICAL LIFE:}

Humans need strong motivation, courage and patience to avoid temptations. This is why prophet has declared the person lucky who is safe from the evil of temptations. But if the temptation is inflicted upon him and he fights it with patience and perseverance. ${ }^{43}$ Therefore, the hearts of the Companions were also aroused and they utilized prophet's company vigorously to obtain objective information. Once prophet was warning the Companions regarding the havoc of temptation, Saeed Ibn Zaid asked prophet "what we should do if we were to suffer any of them. Prophet answered. It will be enough for you to be killed." Hazrat Saeed says that after this I saw my brothers being killed. ${ }^{44}$

Similarly, in another place, prophet mentioned the prevalence of treachery and embezzlement among the people. So, Abdullah bin Umar (RA) asked what he should do in these situations.

He said, "You must hold your house, take control of your tongue, take

\footnotetext{
${ }^{42}$ Muhammad ibn 'Īsá ibn Sawrah Jami' at-Tirmidhii (Hamas: Maktabh Daruddawah, 2643)

${ }^{43}$ Abu Daud Sulaiman Bin Ashat Assajastani, Sunan-e-abu daud (Daru Hadith letaba wannaser, Beirut, Hadith-4263)

${ }^{44}$ Abu Daud Sulaiman Bin Ashat Assajastani, Sunan-e-abu daud (Beirut: Daru Hadith letaba wannaser, 4277)
} 
The Scholar Islamic Academic Research Journal

Vol. 5, No. 2 || July -December 2019 || P. 100-127

https://doi.org/10.29370/siarj/issue8ar12

whatever feels good, and release what is evil, and only worry about yourself". 45

People who are worried about their belief and dogma are always trying to get to the bottom of it, if any suspicious or dangerous element tries to get into their religious affairs. They try to eradicate the root causes which can lead to fatalities. In this sense, the knowledge of tribulation traditions becomes very important because in some cases it also leads to the survival of human life. According to a Hadith, due to abundance of tribulation, the atmosphere of jealousy and civil war among the Muslims will be established and they will start cutting off the necks of their own brothers and sisters, making the earth unsafe for human life. He also pointed out that in the human world, the market for slaughter will be hot and a group of Muslims will be united and committed to the pursuit of peace, with those responsible for this corruption. ${ }^{46}$

Trying to convince offspring of Adam by offering sacrifices of their own lives would be a reflection of the fact that its workers are aware of all the intellectual, theological and military references to dealing with corruption. That is why when prophet trained the companions with regard to the future situation and informed them of the rulers who would set up a system which contradicts religion and Shariah, then question Abdullah bin Masood posed a question to prophet: "What attitude should Muslim take in such situations?" "Disobedience to such tyrant rulers' orders and obedience to the injunctions of Allah should be the order of the day for a

\footnotetext{
${ }^{45}$ Abu Daud Sulaiman Bin Ashat Assajastani Sunan-e-abu daud ( Beirut : Daru Hadith letaba wannaser, 4343)

${ }^{46}$ Abu Abdullah Muhammed Bin Yazid Al Kazveni, Ibn-e-Maja Sunan Ibn-e-Maja

(Cairo: Ahyaul Kutub al Arbia, ,2865)
} 
The Scholar Islamic Academic Research Journal

Vol. 5, No. 2 || July -December 2019 || P. 100-127

https://doi.org/10.29370/siarj/issue8ar12

true believer in such dilemma."

\section{CONCLUSION:}

Community of Muslims got adequate knowledge of the nuances of the political aspects of human life, so that they could have a deeper understanding of the trials and concerns that the rulers and politicians have with them. It was informed to the Prophet through divine revelation that in the coming times the reign would be in the hands of those who would be harmful and fatal to the people. Therefore, according to a Hadith from Hazrat Abu Hurairah (RA), prophet warned the Ummah that those who were corrupt and dishonest, they would be trusted during the times of temptations and those who are honest and true to their duty would be denied. The result will be that the ungodly people will do a lot of corruption and keep the looting market hot. One of the bad things in their attribute is that they will also interfere in the domestic affairs of others.

Understanding the teachings of such traditions is very important for the people of Pakistan today as there are some people in the national politics stream whose favorite interests are to slip on the family, business and domestic affairs of the opposition party and covering their own corruption in secret. If the eyes of the public cannot be opened in time, the country may suffer from a major political and administrative difficulty. Considering the reasons, it appears that the primary reason for the entire nation's start in political persecution is that the rule here has been commercialized, which is not to establish public welfare and Islamic system, but to fill the rulers' own personal interests. Because everyone is concerned about the protection of their property and their wealth, they are criticizing each other and taking the path of contempt. According to the tradition of Hazrat Abdullah Ibn Umar, prophet has already warned in this 
The Scholar Islamic Academic Research Journal

Vol. 5, No. 2 || July -December 2019 || P. 100-127

https://doi.org/10.29370/siarj/issue8ar12

regard. It was that when the rulers abandon the Book of Allah to make decisions according to it, divisions will be made between them by Allah. So we see that the languages of the rulers have become as disgusting as the currents of swords are sharp. In one of the Hadīth that have been narrated by Ibn-E-Umar, Prophet (P.B.U.H) made it clear that in the time of temptation, due to tongue there will also be massacres.

In fact, the current political scenario is a reference to prophet's traditions manifestation, because he reported that the links of Islam will be broken one by one, the first of which will be the of prophet and the last shall be prayer (prostration). There have been several verdicts (fatwas) against the Muslim ruler and their killing. Some of these scholars have declared the departure (impeachment) mandatory while some have declared it unnecessary, though prophet has forbidden the killing of a Muslim ruler. However, the failure of spreading the knowledge of the Ahādīth has led to the conclusion that the life of any ruler is no longer safe.

The murder of Khan Liaquat Ali Khan, Benazir Bhutto, etc. in the history of Pakistan is clear examples of this. Of course, these killings were not committed by the people of Șhāriāḥ ideology, but they were driven by political and material motives, but the killing of a Muslim ruler is still a serious and heinous sin.

Prophet (P.B.U.H) has given clear teachings in this regard. Imam Ahmad Ibn Hambal has quoted the tradition of Hazrat Abdullah bin Hawala, according to which Prophet said that whoever avoids my killing, the steadfast caliph and the adherents of the Antichrist will be saved.

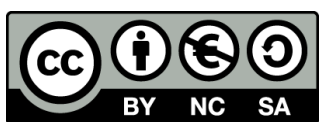

This work is licensed under a Creative Commons

Attribution-NonCommercial-ShareAlike 4.0 International (CC BY-NC-SA 4.0) 